\title{
Creation and quality characterization of processed cheeses derived mainly from Halloumi cheese
}

\author{
Stelios KAMINARIDES*, Dimitris KALOGRIDIS, Theophilos MASSOURAS \\ Laboratory of Dairy Technology, Department of Food Science and Technology, Agricultural University \\ of Athens, Iera Odos 75, Votanikos, 11855 Athens, Greece
}

Received 9 September 2005 - Accepted 3 April 2006

\begin{abstract}
Four new types of processed cheese based on Halloumi cheese were produced. Each cheese had the same concentration of dry matter (53\%) and fat in dry matter (65\%), but the constituents (Halloumi cheese, Kopanisti cheese, strained yoghurt, butter, emulsifiers and water) differed in concentration. Significant statistical differences were noticed in the total protein, water-soluble protein, lactose, ash, $\mathrm{pH}$, hardness, springiness, adhesiveness, cohesiveness, gumminess, chewiness and organoleptic characteristics of the cheeses produced. In all these cheeses, the total microbial flora was low. Yeasts and molds were detected in some samples, but at negligible levels. There were no coliforms. The most important volatile aromatic components of these four types of processed cheese were ethanol, acetone, butanoic, hexanoic and acetic acids. On the basis of the organoleptic assessment the most desirable product was the one that contained $57.8 \%$ Halloumi cheese, $17.7 \%$ butter, $14.1 \%$ water, $7.9 \%$ strained yoghurt and $2.3 \%$ emulsifiers.
\end{abstract}

processed cheese / Halloumi cheese / texture / volatile compounds

掏柽 - 以 Halloumi 干酪为主在制干酪的制造和品质特性。本文系统地研究了以 Halloumi 干 酪为主的四种在制干酪的生产和品质特性。每种干酪的干物质含量 $(53 \%)$ 和脂肪占干物质 的含量 $(65 \%)$ 相同, 但在干物质中各种组成物质 (Halloumi 干酪、Kopanisti 干酪, 篮滤 酸凝酪、奶油、乳化剂和水分）的含量不同。每种干酪的总氮、可溶性氮、乳糖、灰分、 $\mathrm{pH}$ 、硬度、弹性、胶粘度、粘结性、胶黏性、咀嚼性和感官特性指标具有显著性的差异。 在所有的干酪样品中菌落总数较低, 一些样品可以检测出酵母菌和霉菌, 但是低于规定的 质量标准, 所有样品未检出大肠杆菌。酉种在制干酪中主要的芳香化合物成分是乙醇、丙 酮、丁酸、己酸和乙酸。感官分析结果表明, 最佳的产品是由 $57.8 \%$ Halloumi 干酪、 $17.7 \%$ 奶油, $14.1 \%$ 水分, $7.9 \%$ 笁滤酸凝酪和 $2.3 \%$ 乳化剂制成的在制干酪。

\section{在制干酪 / Halloumi 干酪 / 干酪 / 质构 / 芳香化合物}

Résumé - Fabrication et caractérisation de fromages fondus à base principalement de fromage Halloumi. Quatre types de nouveaux fromages fondus basés sur le fromage Halloumi ont été fabriqués. Tous les fromages ont été préparés à partir de matières premières contenant principalement du fromage Halloumi et diverses matières comme le yaourt égoutté, le beurre, le fromage Kopanisti, de l'eau et des émulsifiants. La proportion de ces matières a été calculée de façon à ce que tous les fromages fabriqués aient la même concentration de matière sèche $(53 \%)$ et matière

\footnotetext{
* Corresponding author (通讯作者): skamin@aua.gr
} 
grasse dans l'extrait sec $(65 \%)$. Des différences statistiques significatives ont été notées dans la teneur en protéine totale, protéine hydrosoluble, lactose, cendre, $\mathrm{pH}$, et pour la dureté, l'élasticité, l'adhérence, la cohésivité, la viscosité, la masticabilité et les caractéristiques organoleptiques des fromages fondus obtenus. La flore microbienne des fromages est restée dans tous les cas à des niveaux assez bas. Des levures et des moisissures ont été trouvées dans certains échantillons à des niveaux négligeables. Il n'y avait pas de coliformes. Les composés volatils les plus importants étaient les aldéhydes, les alcools, les cétones, les esters et les acides (butyrique, hexanoique et acétique). Le produit le plus satisfaisant était celui qui a contenait 57,8 \% fromages Halloumi, 17,7 \% de beurre, $14,1 \%$ d'eau, 7,9\% de yaourt égoutté et 2,3\% d'émulsifiant.

fromage fondu / Halloumi / texture / composés volatils

\section{INTRODUCTION}

According to the Greek Codex Alimentarius [10], processed cheeses for slicing or spreading are products that are prepared with milling, mixing, melting and emulsification of various types of cheeses, with heating and addition of the emulsifying salts and the required amount of water, with or without the addition of milk and/or other products. The production of processed cheeses began before the First World War and has since increased continuously because of the advantageous properties they offer [25, 29]. Although processed cheeses have been studied worldwide [2, $12,34]$, in Greece they have not yet been researched widely [20]. This study took place in the Dairy Laboratory of the Agricultural University of Athens and its main aim was the production and study of new types of processed cheese derived from Halloumi cheese. Halloumi cheese is a traditional and distinctive cheese of Cyprus. Its unique characteristics as a product for raw consumption or cooking (primarily grilled or fried) have made it widely popular in the Middle East, the European Union, Australia and the USA. More recently, the product has gained international acceptance and recognition. The committee for standards of the Cyprus Ministry of Commerce and Industry [8] established the definition and standards for Halloumi cheese. The Halloumi cheese-making procedure is described by Anifantakis and Kaminarides [3]. Papademas and Robinson [28] have recently reviewed data related to this type of cheese. Halloumi cheese has a lot of advantages because it is a semi-hard cheese without a rind, suitable for slicing, and keeps very well in a deep-frozen form. It has particularly pleasing organoleptic characteristics, and gives a good, constant texture to processed cheese. The objective of the present study was the creation of four types of processed cheese that would have almost the same dry matter $(53 \%)$ and fat in dry matter contents $(65 \%)$, so that they have excellent quality according to the Greek Codex Alimentarius [10]. However, in the final product the various constituents of Halloumi, Kopanisti, strained yoghurt, butter, emulsifying salts and water participate in different concentrations. Kopanisti cheese is a traditional and Protected Designation of Origin (PDO) Greek cheese which is produced in the Cyclades islands of the Aegean sea. Its main characteristics are the intense salty and strong piquant taste, the soft and spready texture and a sharp peppery flavor, which in good quality cheeses approaches that of Roquefort cheese. The main features of its manufacturing are: (a) the curdling of milk by the combined action of a small quantity of rennet $(0.3 \%$ g rennet $\cdot 100 \mathrm{~kg}^{-1}$ milk) and the acidity produced by the flora of the raw milk, and (b) the acid curd thus formed after the removal of the whey is mixed with $\mathrm{NaCl} 4 \%(\mathrm{w} / \mathrm{v})$ and $10 \%$ of good quality mature Kopanisti cheese and left to ripen, preferably in cool and humid stores. Under these conditions a rich surface growth of microflora occurs some days later, followed by incorporation by kneading throughout the cheese mass. This treatment is repeated until the cheese obtains its desired sensory properties. More information about the technology of Kopanisti cheese is given by Kaminarides and Anifantakis [17]. The microbiological and physicochemical properties of Kopanisti 
Table I. The relative proportions of constituents (\%) in the four processed cheese blends A, B, C and D.

\begin{tabular}{lcccc}
\hline Materials & \multicolumn{4}{c}{ Processed cheese blends } \\
\cline { 2 - 5 } & $\mathrm{A}$ & $\mathrm{B}$ & $\mathrm{C}$ & $\mathrm{D}$ \\
\hline Halloumi cheese & 61.87 & 59.16 & 57.78 & 55.81 \\
Kopanisti cheese & - & 9.10 & - & 7.44 \\
Strained yoghurt & - & - & 7.91 & 7.44 \\
Butter & 17.06 & 14.90 & 17.71 & 15.90 \\
Emulsifying salts & 2.64 & 1.82 & 2.53 & 1.86 \\
Water & 18.43 & 15.02 & 14.07 & 11.55 \\
\hline
\end{tabular}

cheese during ripening were studied by Kaminarides and Anifantakis [18] and Kaminarides et al. [21]. Strained yoghurt is a type of Greek-style yoghurt, which is strained traditionally in cloth bags or centrifuged in a similar way to that of Quarg cheese, or ultrafiltrated by big plants. This product has an acidic flavor and a creamy consistency due to the drastic reduction of serum. Finally, the effect of the concentrations of these constituents on the physicochemical, rheological, aromatic and organoleptic characteristics of the resultant products were studied.

\section{MATERIALS AND METHODS}

\subsection{Selection of raw materials}

\subsubsection{Cheeses and strained yoghurt}

Cheeses, based on chymosin curd, were obtained from the pilot plant of the Dairy Laboratory of the Agricultural University of Athens. To ensure the desired firmness at cutting of the products, a large quantity of Halloumi cheese, with a high portion of intact casein, was used. The Halloumi cheese had a characteristic aroma, an elastic and compact texture and its fat and total solids contents were $28.5 \%$ and $55 \%$, respectively. To enhance the flavor of the products a smaller amount of mature Kopanisti cheese and/or strained yoghurt were used. The Kopanisti cheese had a sharp flavor and its fat and total solids contents were $28 \%$ and $45.4 \%$, respectively. The strained yoghurt was obtained from the local market, had an acidic flavor and a creamy consistency and its fat and total solids contents were $8 \%$ and $23 \%$, respectively.

\subsubsection{Emulsifying salts}

A combination of trisodium citrate, disodium monophosphate and sodium hexametaphosphate (Graham's salt) in a ratio of $1: 3: 6$, respectively, was chosen and used according to the various characteristics of emulsifying salts and other raw materials of the blend as well as the desired requirements of the processed end products. The amount of emulsifying salts added to each blend (Tab. I) was related to the portion of unhydrolyzed casein of raw dairy material used.

\subsubsection{Milk butter}

Milk butter was obtained commercially. Butter was used to adjust the fat content of the blends so that all the types of processed cheese contained $65-66 \%$ fat in dry matter.

\subsubsection{Water}

Distilled water was used to adjust the moisture content of the blends, so that all the cheeses contained about $47 \%$ moisture.

\subsection{Cheese-making technology}

The manufacturing procedure for processed cheese was carried out in the following order:

- Selection of a stock of raw materials. 
- Computation of the ingredients in the various blends. For the computation of the quantity of the ingredients to be processed two very important calculations are required. The first is the estimation of the amount of butter required in the mix. It is found by solving an equation that represents the fat in dry matter of all the raw materials needed except the water, which is required in the finished mix. The second is the determination of the amount of water to be added to the raw materials to give the required dry matter in the finished mix.

- Preparation of cheese (coarse cutting of the Halloumi cheese).

- Weighing and mixing of the raw materials in containers before processing.

- Premixing the emulsifying salts with the required amount of water.

- Thermal processing (heating with agitation at $80^{\circ} \mathrm{C}$ for $5 \mathrm{~min}$ in a water bath).

- Distribution of the hot mixture into cups of $250 \mathrm{~mL}$ volume and sealing by evacuation in plastic pouches.

- Cooling of the products at room temperature.

- Preserving in cold storage at $5^{\circ} \mathrm{C}$.

\subsection{Experimental planning and sampling}

The concentration of materials that were used for creating the four different types of processed cheese is given in Table I. Four parallel cheese-making trials for the four different types of processed cheese with five repetitions from each trial were conducted. All analyses were performed in triplicate and the results are presented as the average of fifteen analyses per each type of processed cheese during the first day of their production.

\subsection{Enumeration of microorganisms}

The cheeses were examined on day 1 . Samples $(50 \mathrm{~g})$ of cheese were transferred under aseptic conditions to a Petri dish and analyzed on the day of sampling. A sample $(5 \mathrm{~g})$ was suspended in $20 \mathrm{~g} \cdot \mathrm{L}^{-1}$ trisodium citrate $(45 \mathrm{~mL})$ to give a 1:10 dilution. Further decimal dilutions were prepared in $1 / 4$ strength Ringer's solution. The total microbial flora was enumerated by the pour-plate method of the American Public Health Association [5] using Plate Count Agar (Difco, Michigan, USA) with incubation at $30{ }^{\circ} \mathrm{C}$ for $2 \mathrm{~d}$. Coliforms were enumerated according to IDF [14] using MacConkey broth (Oxoid, Hampshire, England) with incubation at $37^{\circ} \mathrm{C}$ for $2 \mathrm{~d}$. Yeasts and molds were enumerated using yeast extract glucose chloramphenicol agar with incubation at $25{ }^{\circ} \mathrm{C}$ for $4 \mathrm{~d}$.

\subsection{Physicochemical analyses}

Samples of cheeses were analyzed for total proteins [13] and total solids [15] according to the International Dairy Federation standards, fat according to the volumetric method of Gerber-Van Gulic [33], soluble N (SN) according to Kosikowski's method [23], lactose according to the Acton method [1], ash as specified in the AOAC [4] and the $\mathrm{pH}$ was measured with a $\mathrm{pH}$ meter (model 632, Metrohm, Herisau, Switzerland). All analyses were performed three times for each sample.

\subsection{Texture evaluations}

The textural properties of cheeses were measured with a Shimadzu testing instrument, model AGS-500 NG (Shimadzu Corporation, Kyoto, Japan), as described by Kaminarides and Stachtiaris [21].

\subsection{Determination of volatile compounds}

Volatile compounds were determined using a gas chromatography headspace system (HS-40, Perkin Elmer) connected to a mass spectrometer (GC/MS, QP 5050, Shimadzu), according to the Kondyli method [22].

\subsection{Organoleptic evaluations}

A panel of 10 judges, familiar with judging dairy products, evaluated the processed cheeses from each trial. Scoring of each 
organoleptic property (appearance, texture, flavor and aroma) was based on the hedonic scale $(0=$ dislike extremely, $5=$ like extremely). Results are expressed as a mean score for the whole panel for each cheese.

\subsection{Statistical analysis}

The results for the four types of cheese were subjected to analysis of variance (ANOVA) using the software Statgraphics (Statistical Graphics Corp. Rockville, Maryland, MD, USA). A randomized complete block design was used and paired comparisons of means were made using the Duncan test $(P \leq 0.05)$.

\section{RESULTS AND DISCUSSION}

\subsection{Enumeration of microorganisms}

There were no significant differences $(P>0.05)$ in the microbial population of the four types of processed cheese. The number of viable mesophilic microorganisms was found to be approximately $10^{3} \mathrm{cfu} \cdot \mathrm{g}^{-1}$ of cheese. This is attributed to the thermal heating of blends $\left(70^{\circ} \mathrm{C}\right.$ for $\left.2-4 \mathrm{~min}\right)$. The populations of yeasts and molds in the four types of cheese were smaller than $10 \mathrm{cfu} \cdot \mathrm{g}^{-1}$ of cheese and are attributed to contaminations, as these microorganisms were inactivated by the pasteurization. Coliforms were not found in any cheese sample.

\subsection{Physicochemical and rheological characteristics}

Statistically significant differences $(P<$ $0.05)$ in the physicochemical and rheological characteristics of the four types of processed cheese were observed (Tab. II). The $\mathrm{pH}$ was lowest in product (D). This may be attributed to the fact that product (D) contained $7.4 \%$ Kopanisti cheese and 7.4\% strained yoghurt, which are dairy products with a low $\mathrm{pH}[19,21]$. In contrast, the highest $\mathrm{pH}$ was observed in product (A), which contained the highest percentage of Halloumi cheese $(61.9 \%)$, which has a high $\mathrm{pH}$, whereas Kopanisti cheese and strained yoghurt were not included in this product. There were no significant differences $(P>0.05)$ in the amount of dry matter, fat and fat in dry matter contents of the various types of processed cheese, which verifies that the standardization of these constituents in the blends was achieved for all the types of processed cheese produced. The higher concentration of lactose observed in the products (D) and (C) may be attributed to the fact that these products contained strained yoghurt, which has a higher lactose content than cheese. The products (B) and (D) contained higher concentrations of total protein and water-soluble protein than products (A) and (C), because in (B) and (D) a larger percentage of cheese was incorporated into the blends $(68.3 \%$ and $63.3 \%$, respectively) than in A $(61.9 \%)$ or $\mathrm{C}$ $(57.8 \%)$. The quantity of ash differed significantly $(P \leq 0.05)$ among all four types of processed cheese and was proportional to the percentage incorporation of emulsifying salts for each blend.

The four types of processed cheese exhibited significant statistical differences $(P \leq 0.05)$ in their rheological characteristics. The highest values of hardness, gumminess and chewiness were found in the product (A), which was prepared with the highest percentage of fresh Halloumi cheese $(61.9 \%)$ and the largest concentration of ash, followed in decreasing order by products (C), (B) and (D). This is due to the fact that processed cheeses (A) and (C) had higher intact paracasein content than the other processed cheeses, since paracasein shows a strong correlation with cheese hardness [9, 31]. From this result it appears that increasing the Halloumi cheese, salt and ash contents of the blend increased the hardness of the resulting processed cheese. Also, the incorporation of the mature Kopanisti cheese in the blend significantly decreased the hardness of the processed cheese. This observation is in agreement with the results of Picka and Stetina [30]. Product (A) also showed the highest cohesiveness, while products (B), (C) and (D) did not differ significantly. The elasticity and adhesiveness of the products (A), (B) and $(\mathrm{C})$ did not show any statistically significant differences, while the product (D) 
Table II. Physicochemical and rheological characteristics of the four types of processed cheese A, $\mathrm{B}, \mathrm{C}$ and $\mathrm{D}$ (means \pm standard error of mean).

\begin{tabular}{|c|c|c|c|c|}
\hline \multirow{2}{*}{ Characteristics } & \multicolumn{4}{|c|}{ Types of processed cheese } \\
\hline & $\mathrm{A}$ & B & $\mathrm{C}$ & $\mathrm{D}$ \\
\hline \multicolumn{5}{|l|}{ (a) Physicochemical } \\
\hline $\mathrm{pH}$ & $5.69^{c} \pm 0.06$ & $5.57^{\mathrm{b}} \pm 0.05$ & $5.65^{\mathrm{c}} \pm 0.05$ & $5.45^{\mathrm{a}} \pm 0.06$ \\
\hline Dry Matter \% & $53.18 \pm 0.09$ & $53.09 \pm 0.08$ & $53.05 \pm 0.06$ & $53.44 \pm 0.18$ \\
\hline Fat $\%$ & $34.8 \pm 0.19$ & $34.4 \pm 0.10$ & $34.6 \pm 0.10$ & $34.7 \pm 0.29$ \\
\hline Fat in Dry Matter \% & $66.33 \pm 0.66$ & $66.05 \pm 0.88$ & $65.74 \pm 0.66$ & $65.80 \pm 0.41$ \\
\hline Lactose $\%$ & $0.95^{\mathrm{a}} \pm 0.05$ & $1.03^{\mathrm{a}} \pm 0.04$ & $1.30^{\mathrm{b}} \pm 0.02$ & $1.36^{\mathrm{b}} \pm 0.04$ \\
\hline $\begin{array}{l}\text { Total Protein } \\
(\text { Total } \mathrm{N} \times 6.38) \%\end{array}$ & $13.44^{\mathrm{a}} \pm 0.32$ & $14.30^{\mathrm{b}} \pm 0.49$ & $13.17^{a} \pm 0.28$ & $14.00^{\mathrm{b}} \pm 0.39$ \\
\hline Total Protein in DM\% & $25.53^{\mathrm{a}} \pm 0.41$ & $27.38^{\mathrm{b}} \pm 0.65$ & $25.00^{\mathrm{a}} \pm 0.48$ & $26.47^{a \cdot b} \pm 0.57$ \\
\hline $\begin{array}{l}\text { Water-Soluble Protein } \\
(\text { Soluble } \mathrm{N} \times 6.38) \%\end{array}$ & $0.76^{\mathrm{a}} \pm 0.03$ & $1.09^{b} \pm 0.05$ & $0.70^{\mathrm{a}} \pm 0.04$ & $1.03^{b} \pm 0.03$ \\
\hline Ash \% & $4.58^{\mathrm{d}} \pm 0.02$ & $3.67^{\mathrm{a}} \pm 0.02$ & $4.33^{c} \pm 0.03$ & $4.03^{b} \pm 0.03$ \\
\hline \multicolumn{5}{|l|}{ (b) Rheological } \\
\hline Hardness (N) & $3.51^{\mathrm{d}} \pm 0.22$ & $2.68^{\mathrm{b}} \pm 0.17$ & $3.07^{c} \pm 0.16$ & $2.26^{\mathrm{a}} \pm 0.14$ \\
\hline Elasticity (mm) & $0.96^{\mathrm{b}} \pm 0.01$ & $0.94^{a \cdot b} \pm 0.01$ & $0.95^{\mathrm{b}} \pm 0.01$ & $0.93^{\mathrm{a}} \pm 0.01$ \\
\hline Adhesiveness (N.mm) & $18.32^{\mathrm{b}} \pm 1.07$ & $17.29^{b} \pm 0.64$ & $17.33^{b} \pm 1.18$ & $12.23^{\mathrm{a}} \pm 1.08$ \\
\hline Cohesiveness (N.mm) & $0.56^{\mathrm{b}} \pm 0.02$ & $0.49^{\mathrm{a}} \pm 0.05$ & $0.51^{\mathrm{a} . \mathrm{b}} \pm 0.03$ & $0.47 \mathrm{a} \pm 0.05$ \\
\hline Gumminess $(\mathrm{N} \cdot \mathrm{mm})$ & $1.95^{\mathrm{d}} \pm 0.07$ & $1.29^{b} \pm 0.10$ & $1.56^{\mathrm{c}} \pm 0.08$ & $1.04^{\mathrm{a}} \pm 0.06$ \\
\hline Chewiness $(\mathrm{N} \cdot \mathrm{mm})$ & $1.84^{\mathrm{d}} \pm 0.04$ & $1.13^{\mathrm{b}} \pm 0.07$ & $1.42^{\mathrm{c}} \pm 0.07$ & $0.91^{\mathrm{a}} \pm 0.04$ \\
\hline
\end{tabular}

Means in the same row without a superscript or with the same superscript did not differ significantly $(P>0.05)$.

had the lowest value for elasticity and adhesiveness and differed significantly $(P \leq 0.05)$ from products $(\mathrm{A})$ and $(\mathrm{C})$. This may be attributed to partial substitution of Halloumi cheese and incorporation of $7.44 \%$ Kopanisti cheese (D), in which casein degradation is intense [21] and $7.44 \%$ strained yoghurt, in which acid curd is inelastic. This appears to be in agreement with Prentice et al. [31] that the rheological role of $\mathrm{Ca}$ paracasein in fresh cheese is to provide a continuous elastic framework for the individual cheese granules. From the above, it is clear that the textural differences of the four types of processed cheeses result from differences in their composition. Since this processed product is primarily for slicing, a fairly firm texture is desirable.

\subsection{Volatile aromatic components}

The production of aromatic compounds in dairy products depends on the type of milk and the method of preparation, as well as the variety of cultures used. The aroma in processed cheeses is influenced by many factors, from inherent properties of the different kinds of natural cheeses and other constituents of processed cheese blends and the technological choices in cheese production. Differing cheese manufacturing practices result in differences in volatile 
Table III. Volatile aromatic compounds in processed cheeses A, B, C and D. Area of peaks of chromatograms $\times 10^{3}$ TIC in arbitrary units (Means \pm standard error of mean).

\begin{tabular}{|c|c|c|c|c|}
\hline \multirow{2}{*}{ Volatile compounds } & \multicolumn{4}{|c|}{ Types of processed cheese } \\
\hline & $\mathrm{A}$ & B & $\mathrm{C}$ & $\mathrm{D}$ \\
\hline Acetaldehyde & nd & 101.8 & nd & 341.4 \\
\hline 3-Methyl-butanal & nd & 160.8 & nd & 106.6 \\
\hline Total aldehydes & & 262.6 & & 448.0 \\
\hline Acetone & 442.3 & 765.4 & 982.7 & 651.1 \\
\hline 2-Pentanone & 15.6 & 208.5 & 157.9 & 188.4 \\
\hline 2-Heptanone & nd & 136.7 & 439.8 & nd \\
\hline Acetoine & nd & 197.6 & 300.4 & 564.8 \\
\hline Total ketones & 457.9 & 1308.3 & 1880.8 & 1404.2 \\
\hline Ethanol & 1428.7 & 16383.3 & 5694.1 & 10610.8 \\
\hline 2-Butanol & nd. & 283.2 & nd & 452.4 \\
\hline 1-Butanol & nd & nd & 165.9 & nd \\
\hline 3-Methyl-1-butanol & 49.4 & 27.4 & 20.8 & 473.3 \\
\hline Total alcohols & 1478.1 & 16693.9 & 5880.8 & 11536.5 \\
\hline Acetic acid & 167.9 & 551.5 & nd & 854.3 \\
\hline Propanoic acid & nd & 183.4 & nd & 267.3 \\
\hline Octanoic acid & 434.6 & nd & 317.3 & nd \\
\hline Butanoic acid & 987.5 & 8766.2 & 3112.0 & 7965.4 \\
\hline Hexanoic acid & 789.8 & 3726.1 & 1253.8 & 3386.8 \\
\hline Total organic acids & 2379.8 & 75227.2 & 4683.0 & 12473.9 \\
\hline Ethyl-acetate & 38.2 & 203.5 & nd & 303.5 \\
\hline Ethyl-butanoate & nd & 867.9 & nd & 687.7 \\
\hline 2-Propyl-formate & nd & 1051.0 & nd & 516.8 \\
\hline Propyl-butanoate & nd & nd & nd & 531.2 \\
\hline Ethyl-hexanoate & nd & 723.2 & nd & 666.3 \\
\hline Ethyl-octanoate & nd & 267.3 & nd & 219.5 \\
\hline Total esters & 38.2 & 3112.9 & & 2925.6 \\
\hline Acetonitrile & 215.1 & 987.6 & 467.5 & 144.7 \\
\hline
\end{tabular}

nd: not detected.

composition, and ultimately differences in flavor and texture among cheese varieties. Around 22 peaks of volatile compounds were found and identified in total ion current (TIC) chromatograms in the four types of processed cheese. The major volatile aro- matic compounds that were detected in the four types of processed cheese were aldehydes, ketones, alcohols, esters and organic acids (Tab. III). Aldehydes such as acetaldehyde and 3-methyl-butanal were detected in products (B) and (D), which contained 
matured Kopanisti cheese. Their quantities represented 0.79 and $1.64 \%$ (based on peak area) of total volatiles, respectively. Nevertheless, these compounds are likely to have an important impact on the aroma of cheese due to their low aroma threshold values. Acetaldehyde can be found in a wide variety of fermented dairy products such as yoghurt, while there has been great diversity in description of 3-methylbutanal flavors in the literature, depending on its concentration and on interaction with other volatile compounds. Four ketones (acetone, 2-pentanone, 2-heptanone and acetoin) were detected in the processed cheeses produced. Ketones have different origins: acetone is mainly derived from animal feed, and 2-pentanone and 2-heptanone have both a natural and a technological origin [6, 11]. During heat treatment the pathways of their formation occur via the oxidation of saturated fatty acids, followed by decarboxylation of $\beta$-ketoacids $[7,11]$. Acetoin can be derived from diacetyl metabolism or from pyruvate metabolism during the conversion of lactose into lactic acid [24] and is characterized by buttery notes. The characteristic ketone that was detected in all four types of processed cheese was acetone, while acetoine and 2-heptanone were detected only in the products (B), (C) and (D) and (B) and (C), respectively. Larger quantities of ketones were detected in the products (C) and (D), which contained strained yoghurt, followed by product (B), which contained matured Kopanisti cheese. Among the alcohols, ethanol, 2-butanol, 1-butanol and 3-methyl-1-butanol were detected in the processed cheeses produced. Ethanol was the predominant alcohol and was detected in all four products. Ethanol may originate from lactose fermentation by several bacteria and yeasts [32]. The largest quantity was detected in product (B), which was produced with the largest percentage of matured Kopanisti cheese (9.10\%), followed by the product (D) with $7.44 \%$ Kopanisti cheese. The high concentration of ethanol in these products is probably due to the substantial yeast flora of Kopanisti cheese [18], whose activity produces large amounts of ethanol via lactose fermentation $[6,27]$. Short-chain free fatty acids $\left(\mathrm{C}_{2: 0}{ }^{-}\right.$
$\mathrm{C}_{8: 0}$ ) were the major class of the volatile compounds isolated followed by alcohols and esters (Tab. III). The most abundant acids detected in all four types of processed cheese were butanoic and hexanoic acids. The largest quantities of short-chain acids were detected in products (B) and (D), which contained matured Kopanisti cheese, followed by product $(\mathrm{C})$, which contained strained yoghurt. The presence of mature Kopanisti cheese was clearly associated with total short-chain acids, especially butanoic and hexanoic acids. Indeed, the rate of liberation of these acids was high during lipolysis of this type of cheese [21]. Octanoic acid was detected in processed cheeses (A) and (C) while propionic acid was detected in processed cheeses (B) and (D) which contained matured Kopanisti cheese. Also, larger quantities of acetic acid were detected in the cheeses (B) and (D) which contained matured Kopanisti cheese. Acetic acid generally characterizes pickled cheeses with a harsh flavor such as Kopanisti cheese. Butanoic, hexanoic and octanoic acids contributed to the cheesy and rancid odors. Of these, butanoic acid showed high aroma intensity. Short-chain free fatty acid content was much higher than that of other Greek varieties of cheese but similar to that of mold-ripened cheeses [21]. Also, FFAs may act as a precursor for other flavor compounds such as ester, methyl ketones and secondary alcohol [35]. Esters arise from esterification of shortchain FFAs with ethanol. Among esters, ethyl-butanoate, ethyl-hexanoate, ethyl-acetate, ethyl-octanoate, propyl-butanoate and 2-propyl-formate were detected in relatively large quantities in cheeses (B) and (D) which contained matured Kopanisti cheese. Large quantities of ethanol and esters are normally associated with fruity flavors [35]. Acetonitrile, detected in all products, is not a metabolite, but has been found in various other types of cheese [16, $26,27]$ and may be attributed to substances left behind after the cleaning of the equipment. The results indicated notable differences between the processed cheese blends (A), (B), (C) and (D). Moreover, we observed that the concentration of the compound in the volatile composition seemed 
Table IV. Sensory evaluation of processed cheeses A, B, C and D 1 day after production (Means \pm standard error of mean).

\begin{tabular}{lccccc}
\hline \multirow{2}{*}{$\begin{array}{l}\text { Organoleptic } \\
\text { characteristics }\end{array}$} & Scale & \multicolumn{5}{c}{ Cheese type } \\
\cline { 3 - 6 } & & $\mathrm{A}$ & $\mathrm{B}$ & $\mathrm{C}$ & $\mathrm{D}$ \\
\hline Taste and flavor & $0-8$ & $5.70^{\mathrm{a}} \pm 0.34$ & $5.90^{\mathrm{a}} \pm 0.33$ & $7.40^{\mathrm{b}} \pm 0.24$ & $6.90^{\mathrm{b}} \pm 0.24$ \\
Texture & $0-8$ & $7.30^{\mathrm{b}} \pm 0.20$ & $5.90^{\mathrm{a}} \pm 0.24$ & $7.10^{\mathrm{b}} \pm 0.24$ & $6.30^{\mathrm{a}} \pm 0.20$ \\
Appearance & $0-8$ & $7.30^{\mathrm{b}} \pm 0.20$ & $6.00^{\mathrm{a}} \pm 0.27$ & $7.30^{\mathrm{b}} \pm 0.20$ & $6.30^{\mathrm{a}} \pm 0.12$ \\
\hline
\end{tabular}

Cheese Cheeses A, B, C and D are defined in Table I.

a,b Means in the same row bearing a common superscript did not differ significantly $(P>0.05)$.

to be important for (B) and (D) cheeses, which contained matured Kopanisti cheese.

\subsection{Organoleptic evaluation}

The results of the taste panel assessment of the quality of the four different cheeses are presented in Table IV. Although the assessment presented here was made on day 1 , it is known that the characteristics of this type of cheese are stable for at least one month after cold storage. Statistical analysis of the mean scores for the organoleptic characteristics of the four types of processed cheese revealed significant differences $(P \leq 0.05)$. The products preferred most for their taste and flavor were $(\mathrm{C})$ and (D). This may be attributed to partial substitution of Halloumi cheese and incorporation of strained yoghurt in the products (C) and (D) and Kopanisti cheese in product (D). Indeed, strained yoghurt mainly with its carbonyl compounds, and Kopanisti cheese with its aromatic compounds, play a significant role in enhancing the flavor of these produced cheeses. In contrast, (A) and (C) were judged to have a better texture and appearance. The partial substitution of Halloumi cheese and the incorporation of Kopanisti cheese only weaken the original texture and appearance of the Halloumi processed cheese. Overall, the best product was (C), which contained $57.78 \%$ Halloumi cheese, $17.71 \%$ butter, $14.07 \%$ water, $7.91 \%$ strained yoghurt and $2.53 \%$ emulsifying salts. Also, it was reported that products (B) and (D) presented a sharp flavor, mainly due to the fact that Kopanisti cheese participated in their preparation $(9.1 \%$ and $7.44 \%$, respectively) and the extent of proteolysis and lipolysis of the Kopanisti cheese used was high [21].

\section{CONCLUSION}

Comparative evaluation showed that the new types of processed cheese derived mainly from Halloumi cheese were of very good quality, as Halloumi cheese has a lot of advantages. Although all cheeses had the same dry matter (53\%) and fat in dry matter $(65 \%)$ contents, they showed significant differences in many characteristics, and these differences are attributed to compositional differences. Of all the blends tested, type (C), which contained $57.78 \%$ Halloumi cheese, $17.71 \%$ butter, $14.07 \%$ water, $7.91 \%$ strained yoghurt and $2.53 \%$ emulsifying salts, gave the most preferable product and can be recommended for the production of Halloumi-based processed cheese.

\section{REFERENCES}

[1] Acton G.H., The determination of lactose cheese, Aust. J. Dairy Technol. 32 (1977) 111-111.

[2] Aly M.E., Abdel-Baky A.A., Farahat S.M., Quality of Processed cheese spread made using ultrafiltered retentates treated with some ripening agents, Int. Dairy J. 5 (1995) 191-209.

[3] Anifantakis E.M., Kaminarides S.E., Contribution to the study of Halloumi cheese made 
from sheep's milk, Aust. J. Dairy Technol. 58 (1983) 29-31.

[4] AOAC, Official Methods of Analysis, 12th edn., Association of Official Analytical Chemists, Washington DC, USA, 1975, p. 254.

[5] APHA, Standard Methods for the Examination of Dairy Products, 12th edn.. American Public Health Association, Washington DC, USA, 1967, pp. 34-52.

[6] Badings H.T., De Jong C., Dooper R.P., Automatic system for rapid analysis of volatile compounds by purge-and-cold trapping/ capillary gas chromatography, J. High Resolut. Chromatogr. Commun. 8 (1985) 755-763.

[7] Contarini G., Povolo M., Leardi R., Prino P.M., Influence of heat treatment on the volatile compounds of milk, J. Agric. Food Chem. 45 (1997) 3171-3177.

[8] Cyprus Ministry of Commerce and Industry, Cyprus standards for Halloumi cheese. CYS/ TS10. CY594: Parts 1 and 2, Nicosia, 1985.

[9] Fernandez del Pozo B., Gaya P., Aedina A., Rodriguez-Aarin A., Nunez A., Changes in chemical and rheological characteristics of La Serena ewe's milk cheese during ripening, J. Dairy Res. 55 (1988) 457-464

[10] Greek Codex Alimentarius, Official Journal of Hellenic Republic (Vol. B, Article 83), National Printing Office, Athens, Greece, 2003.

[11] Grosch W.A., Lipid degradation products and flavor, in: Norton I.D., MacLeon A.J. (Eds.), Food flavour, Chapter 5, Elsevier Science Publichers, Amsterdam, The Netherlands, 1982, pp. 325-398.

[12] Hagrass A.E.A., El-Ghandour M.A., Hammad Y.A., Hofi A.A., The use of recombined milk Ras cheese in the manufacture of processed cheese, Egypt. J. Food Sci. 12 (1984) 129-134.

[13] IDF Standard 25, Determination of protein content of processed cheese products, International Dairy Federation, Brussels, Belgium, 1964

[14] IDF Standard 73A, Milk and milk products Enumeration of coliforms, International Dairy Federation, Brussels, Belgium, 1985.

[15] IDF Standard 4A, Determination of the total solids content in cheese and processed cheese, International Dairy Federation, Brussels, Belgium, 1982.
[16] Izco J.M., Torre P., Characterisation of volatile flavour compounds in Roncal cheese extracted by the 'purge and trap' method and analysed by GC - MS, Food Chem. 70 (2000) 409-417.

[17] Kaminarides S.E., Anifantakis E.M., New Technology of manufacturing of Kopanisti cheese, in: Proc. 2nd National Congress on Foods Science and Technology, Athens, Greece, 1989, pp. 519-534.

[18] Kaminarides S., Anifantakis E., Evolution of the microflora of Kopanisti cheese during ripening. Study of the yeast flora, Lait 69 (1989) 537-546.

[19] Kaminarides S.E., Anifantakis E.M., Characteristics of set type yoghurt made from caprine or ovine milk and mixtures of the two, Int. J. Food Sci. Technol. 39 (2004) 319-325.

[20] Kaminarides S., Stachtiaris S., Production of processed cheese using Kasseri cheese and processed cheese analogues incorporating whey protein concentrate and soybean oil, Int. J. Dairy Technol. 53 (2000) 69-74.

[21] Kaminarides S.E., Anifantakis E.M., Alichanidis E., Ripening changes in Kopanisti cheese, J. Dairy Res. 57 (1990) 271-279.

[22] Kondyli E., Massouras T., Kasiari M.C., Voutsinas L.P., Free fatty acids and volatile compounds of low-fat kefalograviera-type cheese made with a commercial adjuct culture, Int. Dairy J. 13 (2003) 47-54.

[23] Kosikowski F., Cheese and Fermented Milk Foods, 2nd edn., Edwards Brothers, Inc., Ann Arbor, MI, 1977, p. 572.

[24] Law B.A., Flavour compounds in cheese organoleptic properties, Perfum. Flavour. 7 (1982) 9-12.

[25] Meyer A., Processed cheese manufacture, Food Trade Press Ltd, London, UK, 1973.

[26] Munoz N., Ortigosa M., Torre P., Izco J.M., Free amino acids and volatile compounds in ewe's milk cheese as affected by seasonal and cheese-making plant variations, Food Chem. 83 (2003) 329-338.

[27] Ortigosa M., Torre P., Izco J.M., Effect of pasteurization of ewe's milk and use of a native starter culture on the volatile components and sensory characteristics of Roncal cheese, J. Dairy Sci. 84 (2001) 1320-1330.

[28] Papademas P., Robinson R.K., Halloumi cheese: the product and its characteristics, Int. J. Dairy Technol. 51 (1998) 98-103. 
[29] Patart J.F., Processed cheeses, in: Eck A. (Ed.), Cheese-making Science and Technology, Lavoisier, Paris, France, 1986, p. 388.

[30] Picka I., Stetina J., Influence of cheese ripening and rate of cooling of the processed cheese mixture on rheological properties of processed cheese, J. Food Eng. 61 (2004) 551-555.

[31] Prentice J.H., Langley K.R., Aarshall R.J., Cheese rheology, in: Fox P.F. (Ed.), Cheese: Chemistry, Physics and Microbiology, Vol. 1, Chapman and Hall, London, UK, 1993, pp. 303-340.

[32] Sable S., Cottenceau G., Current knowledge of soft cheeses flavoured related com- pounds, J. Agric. Food Chem. 47 (1999) 4825-4836.

[33] Schneider C., Traité pratique des essais du lait et du contrôle des produits laitiers, C.J. Wyss S.A., Berne, Switzerland, 1954.

[34] Tamime A.Y., Younis M.F., Production of processed cheese using Cheddar cheese and cheese base. 1. Aspects of processing, Milchwissenchaft 46 (1991) 423-427.

[35] Urbach G., The flavour of milk and dairy products. 2. Cheese: contribution of volatile compounds, Int. J. Dairy Technol. 50 (1997) 79-89. 